COGNITIVE STUdies | ÉTUdES COGNITIVES, 10

SOW Publishing COGN, Warsaw 2010

JADWIGA WAJSZCZUK

University of Warsaw, Poland

\title{
FUNCTIONAL CLASS (SO CALLED "PART OF SPEECH") ASSIGNMENT AS A KIND OF MEANING-BOUND WORD SYNTACTIC INFORMATION
}

\begin{abstract}
The traditional division of the lexicon into parts of speech which seems to satisfy the requirements of a syntactic description, on the one hand, and a word formation description, on the other hand, cannot be looked upon as a result of a strict classification covering the totality of the lexicon and being based on a coherent set of criteria. Making the criteria more precise or correcting them is an issue of extreme importance and urgency in the work on the theory of language. Such achievements can help solve many other problems, in particular, syntactic ones. The article presents a scheme of several preliminary steps of an amelioration program (a scheme which has been improved compared to the author's earlier attempts going in the same direction). The program is based on combinability characteristics of words, i.e. on those properties that are responsible for the tasks to be accomplished by a given class of expressions in making up a higher order unit, i.e. a syntagm (the author emphasizes this point: it is syntagm rather than sentence which is the category the recommended approach is focusing on), and that, importantly, determine the limits of syntactic rules, i.e. the ins and outs of the rules (the limits concerning the overall stock of words).

Keywords: part of speech, syntactic partitioning of words, functional properties of word classes, two kinds of position opening: with and without semantic impact (syntactic connotation), syntactic lexemes vs. quasi-syntactic (para-syntactic) lexemes.
\end{abstract}

\section{Introduction}

"Parts of speech" is the label of a division of the lexicon into several very general word classes which set up the basic level of grammatical units of language. The characterization of the classes has traditionally included, as one of its three components, meaning attributes of words. The part the meaning considerations have been playing in the process was not altogether clear; still, it has not been called into question, even though it was not as natural as morphological and syntactic characteristics which were so imperative in the reflection on the grammatical structure of Greek or Latin, i.e. those inflectional languages that served as the basis of 
theorizing about parts of speech. The set of the several, not even a dozen, classes emerging from the entire investigation of words, amounted to the fundamentals of the whole of grammar. It might seem that the high rank of the division in question required a kind of embedding in a framework of "world reference". It is nowadays clear that when the word classes emerging from the observation of human speech were assigned certain semantic characteristics, one had to do with just an adornment of sorts: both the most general and a more particularized categorization of the reality, albeit being performed through and in words, materializes at the level of "parts of speech". "Ontological categories" such as object, property, number, action, state, process can be invoked here, but they have no immediate correlates in syntactic classes of the lexicon which no doubt are precisely what the investigation in question is all about. They cannot be vindicated as a coefficient of a functional description of particular words, even if one attempted - following, e.g., Jodłowski (1971: 18-26) - to apply to it an "epistemic" interpretation (nowadays we would probably say: "cognitivistic"). ${ }^{1}$

In contemporary introductions to the theory of parts of speech the semantic coefficient of the characterization of classes is practically speaking non-existent; if one mentions it, after all, one normally distances oneself from it in an appropriate way. The immediate reference of words to the reality and the relevant either general or quite particularized categorization - as already emphasized by Milewski (1952) - constitute an inalienable property of "root" lexical morphemes. Functional properties of words, on the other hand, are, in his opinion, attached to the presence of variously incorporated in a word indicators of such categories as person, case, number, gender, tense, aspect etc. which modify in a multifarious way the lexical meaning already at the word level. These categories differentiate the shapes and forms of words (within the respective paradigms). The relationship between the reality and, on the one hand, those "shapes", on the other hand, individual categories, is extremely complicated, one may even say, whimsical! Milewski tried to delineate morphological categories that are linked to word meanings and syntactically bound morphological categories, but his attempt has not brought any significant results. Nevertheless his endeavour must be appraised as a big step forwards, compared to the earlier moves of the same kind; it lay bare the tremendous complication of the aspect of the linguistic reality at hand.

Notice that the interconnectedness of morphological and syntactic characteristics is quite evident here. The latter ones are concerned with the correlation of word classes with "sentence parts" (classes of functions) such as subject, predicate, attribute, object; notwithstanding the virtual impossibility of any relevant one-to-one correspondences or of any degree of dependencies that would be even minimally significant. Inherent in the mutual relationship of these categorizations

\footnotetext{
${ }^{1}$ The author writes in the relevant context: "a noun denotes, not thing, but so-called "substantiality", i.e. a substantive apprehension [the author's emphasis], of components of the reality; an adjective denotes "attributiveness", i.e. attributive apprehension of a feature, a verb denotes "processuality", i.e. processual apprehension of an action, etc." (Jodłowski 1971: 25-26).
} 
was the question (never asked, by the way): What should be explained by what: "sentence parts" by "parts of speech", or vice versa?

Generative syntax whose significant development was witnessed by the latest half-century and which aimed at offering an account of sentence structure by modeling the structure of combinability of classes adopts its basic terms - noun, verb, adjective, adverb or preposition - simply without defining them. The level of analysis addressing "sentence parts" has been got rid of in this way as an unnecessary burden. The traditional syntactic taxonomy of word classes in this arrangement gets deprived of its main tool.

Other syntactic approaches do not show any interest in elucidation of, or putting some order into, the fundamentals of functional classification of words. Semantic syntax, counterbalancing generative syntax, adopts combinability schemata of particular lexical units (above all, verbal ones) as the basis of its syntactic schemata. While trying to show the immediate dependence of the combinability of words on meaning components of specific lexical morphemes, this approach is prone to programmatically neglect the differentiation of word classes. To an even higher extent do the frameworks of "surface", or formal, syntax feel free of the duty of explaining the secret of parts of speech; they set themselves other specific tasks than an explanation of the structure of language. The contemporary demand seems to be satisfied by a consistently morphological motivation of a partition of the lexicon (Saloni 1974), even if it does not exhaust the whole of it. ${ }^{2}$

In the Polish theoretical linguistics of the latest time attempts have been made to overcome the impasse by constructing the classifications of the lexicon along the lines of a set of purely syntactic criteria. ${ }^{3}$ I shall mention two most important and actively debated schemes in this orientation: Laskowski $(1984 ; 1998)$ and Wróbel (1996, 2001 - with a draft correction). In my opinion the authors' aim has not been achieved, after all. The reason is that the syntactic tools that have been applied do not constitute a coherent conceptual system. Already in the beginning we encounter a recourse to the properties of a word as a sentence constituent: classes of words which are sentence constituents are separated from classes of words which are not such constituents. It might seem that this recourse is fully legitimate; yet it obviously stands in need of an independent definition of sentence and sentence constituent; and we do not possess any definition of sentence that would be free from relying on sentence-creating properties of the verb. Second, a recourse is being made here - in a more or less overt way - to names and properties that are currently being disengaged, i.e. defined (not only to the verb, but also, through the intermediary of the terms superordinate / subordinate member of a nominal group,

\footnotetext{
${ }^{2}$ A very comprehensive and insightful analysis of the troubles with parts of speech, based on a huge literature of the subject, with enormous erudition and rigour is presented by Lyons (1967) in the $2^{\text {nd }}$ volume of his Semantics (Chapter "Semantics and grammar II"; I am drawing on A. Weinsberg's translation 1989). The author shows much reservation with regard to the ontological categories as a semantic foundation of the relevant division, but he tries to justify them linguistically; in the end, he replaces them with the concept of denotational properties of words.

${ }^{3}$ Ulitzka (2008) has given an overview of the Polish works of the 20th century dealing with the division of the lexicon into parts of speech.
} 
to the noun). Third, we encounter a desperate attempt at employing the criterion of the presence / absence of accommodation of forms as surface manifestations of the links between the postulated classes; whereas these are merely symmetrical correlations of morphological categories which are, as such, unreliable, especially for languages structurally different from the inflectional ones. ${ }^{4}$ Thus, the flight from morphological categories has proved not to be wholly possible; nor has one succeeded in avoiding traditional knots of the ignotum per ignotum type or vicious circles (cf. similar objections are voiced in: Gruszczyński (1987), Bobrowski (2003)). What evidently appears lacking is a sufficiently general perspective of description.

Thus, the question arises: Is there any perspective that would secure coherence of syntactic characterizations without invoking the category of sentence at the very start?

I wish to present here a scheme of several preliminary steps of an amelioration program: it is going to be based exclusively on a characterization of combinability potentialities of a word and to materialize the premise that it is not the case that the potentialities result from the general categorial appurtenance of a word to a certain lexical class, but rather, vice versa, that the apprehension of the class distinctions results from the fundamental differences between those potentialities. ${ }^{5}$ It seems that what one has to do with here are meaning-bound functional types of words.

The title of this article sounds slightly cryptic: it announces a claim without revealing it properly. What I wished to emphasize in this way is the idea that the most substantial point in our research is the principle of correlating syntactic properties of words with their semantic properties. However, a certain reasoning which entails that kind of program must be developed at this point.

\section{The starting point; the premises}

The main reason why we address the categories of the syntax of sentence while trying to characterize parts of speech is our awareness that the substantial part of the lexicon serves as the stuff for forming sentences. However, it is imperative at the

\footnotetext{
4 The range of morphological phenomena that accompany combinations of words is limited even in inflectional languages; it is not susceptible of forming a proper image of the mechanisms of functioning of many word classes; this can be seen in Zaron's (2003) scheme where she mainly draws on the indicators of surface syntactic links, without any consideration of the issues relating to the deeper, i.e. semantic, nature of the expressions.

${ }^{5}$ I have been dealing with the topic for many years, cf. the first essays and the successive corrections: Wajszczuk (1992, 1997, 2000, 2005; the latter item with a change in terminology). I have presented certain results during a session of the Committee of the Theory of Language (Committee for Linguistics of the Polish Academy of Sciences) in 2005 in Warsaw and (in the form of a brief Russian version) during the session of the Committee of the grammatical structure of Slavonic languages (International Committee of Slavists) in Petersburg, September 2007. The present text is an extended version of a paper given at the international conference "Mondilex" in the Institute of Slavistics of the Polish Academy of Sciences in Warsaw, June 2009. I am very indebted to Andrzej Bogusławski for translation this my text to English.
} 
very beginning to realize that syntactic criteria can only have to do with that special privileged block — of so called "major parts of speech". The vocabulary is divided by a very distinct caesura; a part of the lexicon remains outside those major classes. It is easily understandable that that part has not attracted particular attention; all the more so because it comprises functionally "auxiliary" classes, such as indicators or exponents of various relations between those basic classes (cf. prepositions or conjunctions as indicators of syntactic links and their discussion in Klemensiewicz $(1967,1969))$.

However, that kind of appraisal does not apply to the whole stock of "auxiliary words". Those among them that are not susceptible to being looked upon as indicators of relations have been taken to have the nature of additional elements outside the limits of a sentence (in particular, exponents of various intellectual attitudes of the speaker). In Laskowski's and Wróbel's classifications the situation does not change after the setting apart of prepositions and conjunctions as linking words; there remains the negatively characterized class of non-linking words. The entire field appears to be non-uniform; the division is not closed.

In the structuralist approach, i.e. in the approach where systemic organization of language is perceived in its every manifestation (language as a system of systems), the main internal caesura dividing the lexicon must be handled with utmost seriousness. Without its being correctly drawn no further procedures can be allowed. The question of whether or not a given word is a sentence constituent leads us to the problem of how to establish and trace that intuitive, albeit by far not self-evident borderline. The criterial question must presuppose in the starting point the homogeneity of the entire field and provide for partial differences because exclusively in this way can we hope to achieve a picture where both completeness and homogeneity of the emerging classes is warranted.

Sentence - this fundamental term of entire linguistics — is a term which it is a most thorny task to define. At the same time it cannot be taken to be intuitively understandable; it cannot be adopted as a simple, initial concept. On the contrary, intuition says that it is the name of something complex, something to be reached by coping with several successive levels of complication, all the way up from the starting point of the word. It is the word alone that can be ascribed the quality of being intuitively graspable and relatively simple. Thus, the success of the entire classificatory enterprise crucially depends on the acceptance of the claim that the function of being a sentence constituent is a consequence of "preestablished", i.e. theoretically prior, properties of the word. ${ }^{6}$ Words are adapted to the task of their being made use of in the basic unit of communication (speech), i.e. sentence

\footnotetext{
${ }^{6}$ Cf.: "Whereas in order to state out of which elements a word consists, an analysis is necessary, the word itself does not constitute an effect of a sentence analysis. This is because the sentence only exists in speech, in the language of discourse, while the word is a unit that exists beyond any discourse; it exists in the mental treasury." (de Saussure 1991: 121). At this point and below (cf. p. 21 and fn.9) I recall fragments of the Cours de linguistique générale which M. Danielewiczowa, the translator of de Saussure's manuscripts into Polish, has drawn the readers attention to in her paper on syntactic schemata (in press).
} 
(the task also includes the most parsimonious, or economical, way of achieving a communicative aim).

The only dimension that can be of some interest to us is that of combinability of words: the source of this is the otherwise trivial statement saying that the stuff underlying sentences can be found exclusively in words with their distinctly determined combinability; it is their semantic predispositions that bring it about that systems of natural languages are called two-class systems. This most general semiotic property of linguistic signs is undoubtedly the best motivated point of departure in the analysis of the principles of their fundamental differentiation. Thus functional differences in the lexicon should be looked upon, in a reversed perspective, as differences in combinability potentialities of words; words described, to be sure, in very general terms, without pointing out specific word classes: such a procedure would carry with it the danger of vicious circles! In an effort to forestall inconsistent views that have become objects of our keen awareness, we have to be wary of certain new kinds of inconsistence.

The center of gravity in the analysis will now lie in the question of modes of differentiation of word combinability. The first difference we identify is the difference between unlimited, free combinability of units of the lexicon and combinability which is restricted in some way. ${ }^{7}$ The predisposition to enter syntactic combinations and to erect the carcass of a sentence is characteristic of expressions which show regimented combinability; the former expressions, the auxiliary ones, exercise other functions: they are at work in a completely different layer, viz. outside the sentence (as we have pictured them in harmony with linguistic tradition). They fill their places on the line of the developing sentence construction, but beyond sentence structures; they do not enter syntagmatic relations with words in juxtaposition with them and do not interfere with strict syntagmatic links between representatives of the major classes, links that the latter enter in the course of "basic articulation" of sentential content. That basic articulation has already been described fairly well in syntax; the principles governing the auxiliary expressions have been described in a much less exact way, but their nature has already come to be understood, at least roughly. The plane where those auxiliary expressions are active in fact constitutes "a second articulation", in other words, the thematicrhematic structure of utterance which avails itself, basically, and in no way without exceptions (this is inherent in their nature)!, of suprasegmental means, i.e. of variation of sounds achieved by stress, pausing, intonation contours, finally, speed and loudness of phonation, i.e. means ideally adjusted to the basic word fabric of sentences. The fine nature of the "second articulation" must be modeled as another layer of a sentence because it has in fact little in common with that crucial syntagmatic string, apart, that is, from their absolute co-existence in the course of materialization of speech — where the "second articulation" constitutes a layer of additional shaping of utterance. The relatively non-numerous segmental devices enriching and modifying the sentence structure, but functioning in it as an extraneous

\footnotetext{
7 This difference was clearly seen already by Misz (1968/1981) in his preliminary study of particles; however, this outstanding scholar did not yet perceive the affinity between particles and conjunctions with respect to the distinction pointed out here.
} 
and heterogeneous ingredient deserve much more attention than it was the case in research that has been carried out heretofore. ${ }^{8}$

Awareness of the presence of different layers within the tangle of "a sentence as used in a concrete situation", often called, after Klemensiewicz, "an utterance" (to make it distinct from what is called simply a sentence), makes it imperative to seriously correct our approach to the so-called "fundamental unit of communication". What we are accustomed to call sentence is not a specific "syntactic product", but an alternative of possible syntagms with their perfectly organized ways of linking constituents and fully automatic (failing to have their entries in a catalogue and as a rule not reaching the level of consciousness) means of possible materialization which is going on on fairly numerous levels and deserves — in harmony with de Saussure's amazing intuition — special attention, more exactly, deserves becoming an object of science with a status different than that of objects in traditional subdomains of linguistics.

It is rules governing the structure of utterances as phenomena of parole that determine which XXX segment can represent that "product": interestingly, it may be a single syntagm, under circumstances consisting of one word, or even, in an extreme case, it may be such a heterogeneous "modifier" of the sentence structure, if only it is in a position to assume responsibility for "canceling" the structure. The endowment of sentence as a basic unit of speech (in the parole plane) is not confined to its comprising a specific syntactic construction. This is one possible way of how de Saussure's claim that the sentence, which is otherwise a kind of syntagm, in fact belongs to the plane of parole as the main unit of that plane is to be understood: "A sentence is a kind of syntagm par excellence. Still, it belongs to speech rather than language" (de Saussure 1991: 149). ${ }^{9}$

The most important conclusion to be drawn from this analysis provides for the nature of the first necessary and substantial steps in classifying the lexicon. The central premise here, let us repeat it, is the statement to the effect that expression combinability is determined by meanings of words. However, it will be remembered that what we have in mind here is not meaning in its narrowest sense, such as is represented by the common root property of the whole range of basic words and their derivates in various classes (cf., e.g., the series: biały, biali, biało, białawy, biel, białość, bielić, bielit, wybielić, pobielić, rozbielić, bielić sié, bielony, zbielały, bielenie itp.), but what constitutes general or categorial value, understood not in the ontological or epistemic mode: it must rather be understood purely linguistically. It is its status that we are trying to identify while presuming that it is inherently

\footnotetext{
${ }^{8}$ The fact that they can be registered does not change the situation of their having an altogether different nature. In this connection, cf. the closed class of so called "interruptors" recently pointed out by Śledź (2007) and taken care of by Grochowski in his classification of uninflected lexemes (in an older version and in a later substantially improved version); in this classification "interruptors" are placed side by side with a tight entanglement of adverbs and particles. Such an arrangement dos not offer an adequate image of real functions of the relevant words.

9 And he continues: "in the domain of syntagms there is no distinct boundary between a fact of language, marked for its collective use, and a fact of speech which is dependent on individual freedom" (de Saussure 1991: 150).
} 
linked to a certain stock, partly overt, of special morphological devices of their own which are subservient to that meaning.

The point is that when we ask what it is that the division of lexical items into so called "parts of speech" pertains to, we cannot forget or ignore the fact that languages (languages in general, not just Polish) tend to determine the membership of syntactically functional classes of expressions no later than at the very level of word formation. Languages utilize, with an eye to making the classes distinct, specialized morphemes, so called "structural formatives", some of them belonging to the category of "transpositional" devices, various simple, extended, negative, finally, so called paradigmatic ${ }^{10}$ means, which (synchronically!) transform, on a very large scale, verbs into nouns and vice versa, nouns into adjectives and vice versa, adjectives into verbs and vice versa, as well as adjectives into adverbs (in the latter case, notably, not adverbs into adjectives, at least not in the domain of word formation; here, the products do not exceed similarity or parallelism! $\left.{ }^{11}\right)$. This problem has received due attention in Lyons' Semantics (see the Chapter recalled earlier on; I refer to Lyons 1989: 56-121). That "transpositional word formation" requires a careful study; the significance of this phenomenon must not be underestimated, especially in view of the fact that the basic word formation elements are never words with unregimented combinability. Within the confines of their field certain types of "transcategorization" may make their appearance, but this phenomenon has a very special mode of being.

In the domain of syntactemes it would be reasonable to consider the possibility of postulating the presence of a "functional marker" in every lexeme, which otherwise does not exclude a zero manifestation. Such a marker would have its place in the structure of a given expression, regardless of what linear position an inflectional morpheme occupies in it, if any such element is present in the first place. The division of parts of speech into inflected and uninflected ones would be waived at this level of analysis, given that such a division is a superfluous reflex of purely morphological observations.

The level of units called "parts of speech" (to use once more that inexact, misleading term) is the word-bound level of units of language, a level higher than that of lexical morphemes where the latter undergo an "adjustment" through an accretion of "functional markers". These are instrumental in a perspicuous "package" of their content, are a kind of endowment which is necessary in certain ways of linking it to that of other expressions resulting in units of a next higher order: word groups or syntagms (according to highly specialized rules, along the lines of a very sophisticated perspectivistic policies, along the lines of a perfectly well suited "political economy"). The incorporation of a "functional marker" in a given word

${ }^{10}$ The concept of "paradigmatic formative" should probably be made more precise since it is unlikely that the quality of a set of inflectional morphemes carries the value of a formative (cf. wilczy vs. wilki).

11 This remark draws on Bogusławski's interesting work on the vast domain of semantic derivation of adverbs from adjectives and the rules thereof, cf. his (2003). I cannot discuss this problem in detail here; nor can I discuss various controversies concerning adverbs in new formal approaches (adverb as one of the forms of the adjective (Saloni 1974), adjective with a neutralized opposition of forms of case (Topolinska 1984)). 
brings it about that the information of its syntagmatic potentiality is transferred to the next level even in cases where the potentiality does not currently materialize.

Let us take stock of our consideration so far. The hope that the division of the vocabulary of a natural language which is utilized by that language as a system will be reconstructed and made accessible can only be satisfied with a reasonable amount of probability if the promise is perceived that is offered precisely by that change of perspective in a linguistic description, with its final goal of detecting the properties of word as a sentence constituent, rather than with the latter being taken as a point of departure, in accordance with what is customary in the literature of the subject, but inevitably involves a vicious circle (let us leave aside, for the time being, the issue of what is universal and what is language specific in idioms that happen to be found in the world; this investigation frontier has been shown in an interesting way by Lyons (ibidem), and earlier by Jespersen (1924)). Syntactically relevant information about word combinability which is conveyed by the appurtenance of words to structural classes and which is given to every language user (which is given in a dictionary as the content of an entry) together with his linguistic competence is apt at distinguishing structural building stuff (grammatical units of a higher level) from means employed in organizing what manifests itself as an utterance (i.e. sentence in use).

I presume that knowledge of meanings of words is inseparable from the ability to distinguish the lack of any semantic relationship between words from the presence thereof. I call combinability properties of a word in a broad sense its generalized aptitude to open, in virtue of lexical meaning in its strict correlation with the value of its "functional marker", at least one position for an open substitution class of other expressions whereby it entails a non-empty contact. The concept of "empty / non-empty contact" which seems to me to have a fundamental character was put to work by Bogusławski (1966) in his monograph on Russian numerals. While preparing conceptual tools for a description of the class of numerals he presented, in the introductory chapter, an outline of vitally important general prerequisites of a grammatical picture of language based on structural premises. One finds there a strict program of a "functional" description of linguistic structures, i.e. of a description of units of a given level of language as "dynamic" entities which transform, by embracing the form-creating values of the next higher level, meanings of the former level into semantic units of the latter level, endowed with new functional properties which secure their status of performers of new tasks.

On the other hand, "combinability properties" of a word in their narrower sense, i.e. a syntactic requirement, will be the name of its aptitude to open in its environment, in virtue of its wholesome lexical meaning, i.e. in a strict correlation with the value of its "functional marker", at least one position for an open substitution class of expressions which is semantically specified, in the sense of its imposing certain definite restrictions on the meanings of the words that are suitable to fill it. Clearly, what is at stake here is complementation, or enrichment, of the meaning of given word; in other words, what materializes here is what is meant when the well known term syntactic connotation is used. Linguistic competence of a language user allows him or her intuitively to distinguish meanings of words 
which can fill such a position from those which cannot fill it, on pain of a strong feeling of incorrectness.

\section{The preliminary and the introductory (basic) criterion of a division of lexemes}

Presence / absence of combinability properties in their broader sense is applied as the preliminary criterion (criterion 0); it allows us to make the counterdistinction of, on the one hand, the vocabulary of a given natural language (with its conventional label of lexemes), and on the other, spurious units of language, or quasi-words (better: paralexemes). The properties of the latter make us handle them as units which in fact belong to other, separate semiotic systems, one-class systems, merely associated with natural language, cf. interjections and appeals, but also specialized phatic signals. This is a consequence of the commonly accepted definition of natural language as a two-class system.

The latter items are not aptly called words. They do not share with the basic stock of the vocabulary of natural language, practically speaking, any common features apart from their articulation into sound elements; even in this regard there is no strict analogy. The point is that those quasi-words render their meaning oppositions through various sound features of phones, syllables and combinations thereof which go beyond the phonological system of a given language, cf., e.g., the various modes of uttering a single articulated sound, the vowel [a], or quantity distinctions in materializing interjections which express, inter alia, astonishment, surprise, amazement, on the one hand, and joyful reminiscence, nasty reminiscence, uneasiness in recalling something or, finally, reiteration of short utterances of a basic sound in a quick succession (staccato), with arbitrarily prolonged and shaped modification of the latest minimal utterance with the purpose of signaling that the speaker is involved in a process of recalling something or rather finding a trace of something: A-a-a-a-a-a ...!), etc. It is worth noticing that features of this kind do not make up in speech any proportional arrangements in the strict sense of the word.

One used to say, reasonably in a way, that words of this sort tend to function as utterance equivalents. But it is mandatory to make the following reservation: those "equivalents" are deprived of any traces whatsoever of an internal meaning structure or dismemberment. In their capacity of wholes without an internal structure they can only be compared to very simple semiotic messages (in their contradistinction to symptoms: sighs, groans, moans, sobs etc. they must be classed as signals), e.g., to a cry of a bird (the example comes from Bühler 1934, here: 2004). In no way, therefore, can they be approached as equal to the basic stock of the vocabulary whose main division yields occasional words (cf. I, here, now) and predicative words having nothing in common with the former ones. An act of utterance in natural language makes its appearance in the framework of that duality of functions. ${ }^{12}$

${ }^{12}$ The status of onomatopoetic expressions is quite different in this respect: more often than not these are sound strings in material supposition, not being used in the primary 
As soon as we discard paralexemes, we reach the point of "closing" the boundaries of the vocabulary. I set much store with this step because the correct starting point is a warrant of an adequate interpretation of other data. In so far as lexemes are combinable units, it is kinds and features of that combinability that must be investigated. As the most basic criterion the question arises of whether lexemes undergoing an examination exhibit connotational properties, or combinability features in their narrower interpretation (criterion I.). This property allows us to set up the following two basic classes: that of lexemes which positively meet the criterion, i.e. enter syntactic relations (syntactemes), and that of lexemes which do not meet it; the latter may open certain positions, but only positions without that kind of characteristic (paratactemes). Combinations of the latter type cannot be called syntactic.

An exact analysis of the field of paratactemes shows that it is outside the syntax of sentence; here, one begins to be concerned with the plane of its materialization. Lexemes of this type cannot be said to enter relations with expressions they are in juxtaposition with; they rather specify the mode of their use in a given utterance; they are means of commenting on what has been said or is to be said; they are placed, as it were, on a higher level. That second mechanism of functioning has to be kept distinct by using an adequate terminology. Following the moment when we reach a more exact understanding of those combinability mechanisms, the relevant part of the vocabulary (particles and conjunctions; cf. the statements below) should be taken to be operators of the "meta" level or utterance or metaoperators, and thus a kind of metatextual operators.

Here is a summary of what has been said (cf. Schema 1 below) in the form of questions concerning a given item that is being examined.

\section{THE WHOLE OF THE VOCABULARY}

0. Whether or not the item opens any position?

I. Whether or not the item opens semantically marked positions or is entered in one of them?

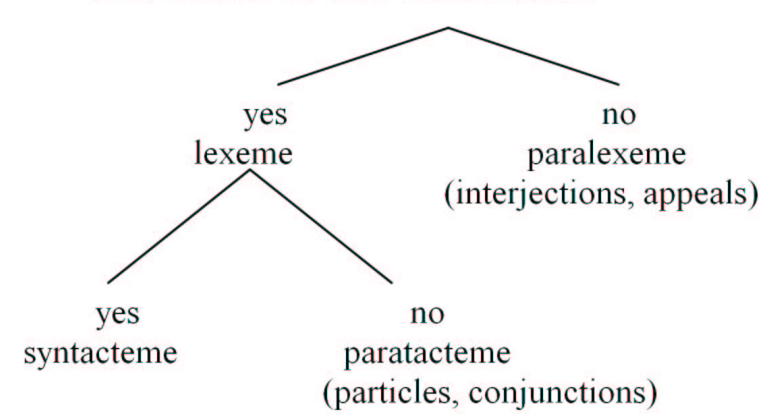

Schema 1. Two preliminary assumptions ${ }^{13}$

way, or else "linguistically elaborated" expressions (elaborated by being endowed with a "functional marker") and used as substitutes of verbs. In my opinion Bańko's (2008) label "onomatopoetic interjections" as applied to them is unjustified.

${ }^{13}$ Schema 1 as the point of departure in my proposal of a global division does not substantially differ from my earlier publications; however, my earlier proposal has undergone serious corrections which were aiming at more exactitude (terminological changes were introduced earlier in Wajszczuk (2005), cf. also fn. 14). 
There can hardly be anything surprising in the fact that the results of the application of the two initial combinability criteria resemble the points made in the literature of the subject. Paralexemes correspond to asyntagmatic, syntactemes to autosyntagmatic, paratactemes to synsemantic units in Laskowski's (1984; also 1998, with certain minor changes) terminology. However, the change of the content of the criteria has brought about serious differences in the denotation of the terms subordinate to particular nodes; hence, the necessity of the alterations that can be seen in the schema above. I shall call the Reader's attention to just one difference which is, however, telling enough: the place of prepositions! They now belong to syntactemes because those among them which can be taken to play the part of units of language enter (two simultaneous) syntactic relations (in the strict sense adopted here), their insignificant weight notwithstanding (which does not allow them to occupy the position of a sentence constituent). The change of the content of the criteria has made it possible to better grasp the demarcation line that runs across the lexicon and separates means of setting up the basic structure of the sentence and the ways to develop it (in the course of mirroring the reality) from means of shaping the current speech situation. It is owing to these steps that we first achieve the uniformity of both fields which is indispensable for the correctness of further stages of classification.

The properties of syntactemes ensure their becoming parts of the stuff of complex higher order expressions, i.e. word groups or syntagms, by their being linked (according to certain definite rules) to lexemes filling the prescribed positions. Where that linking process is aided by parallel or adjusted grammatical categories, the schemata of the respective combinations are most easily visible. Still, outside the circle of light that is cast by the modicum of morphology, darkness prevails. The area of uninflected syntactemes - it gradually becomes more and more visible - has received a poor description. The reason was that all of them - to be sure, apart from prepositions which in their supposed capacity of "functional expressions" were not taken into account at all - were approached as various types of adverbs (cf., e.g., their detailed classification in Grzegorczykowa 1975). Our combinability criterion compels us to divide uninflected words hitherto called, in a summary way, adverbs (or, worse still, particle-adverbs) into two classes: adverbs-syntactemes (in all their tremendous multifariousness) and particles-paratactemes (also showing their vast and extremely subtle plurality). The adopted understanding of combinability does not allow us to look upon paratactemes as a separate semiotic system. Yet one cannot content oneself with their negative characterization (lexemes which do not exhibit connotation traits do not enter any combinations). In order to elucidate the properties of both classes, we must construct a new descriptive apparatus, carefully adjusted to their specificity.

\section{The preliminary division of syntactemes}

An exhaustive division of syntactemes exceeds the scope of this treatment; therefore, I shall present here just one preliminary step.

The property of certain word classes opening positions for specific semantic classes of lexemes — quite understandably — has, as its corollary, its contrary 
counterpart, the property of some other classes filling the positions that are open in that way. The two kinds of properties are two sides of the same relation; therefore, the first criterion (criterion I) has the form of an alternative. However, in order to prove what kinds of classes we in fact have to do with, it is necessary to disentangle the knot. The two initial criteria of the internal division of syntactemes (S-I and S-II) simply represent members of the alternative. It is easy to conclude that the result of the application of the criteria proves to be satisfactory.

S-I. Whether or not the item opens semantically marked positions?

S-II. Whether or not the item fills a semantically marked position open for it by other expressions?

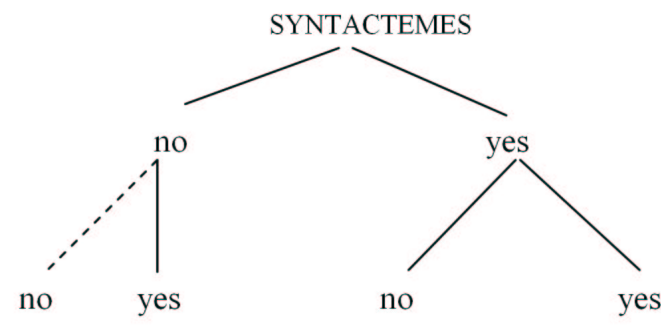

(Ø) (A)

(B)

(C)

Schema 2. Three main classes of syntactemes.

Within the domain of syntactemes three large functional classes of lexemes emerge; each of them is endowed with syntactically relevant properties which mutually co-operate (the position marked as $\varnothing$ is the asyntagmatic one):

Group (A) — syntactemes which do not open any positions, but fill some positions opened by other expressions: "terms"

Group (B) - syntactemes which open some positions and do not fill any positions opened by other expressions: independent predicates

Group (C) - syntactemes which fill some positions and at the same time open positions of their own: dependent predicates

In order to clarify the extension of the classes, I shall adduce some relevant examples; I shall retain their traditional class assignment. Notice that the corresponding labels only help get some orientation; they do not play any substantive part in the arising classification. Here is the relevant presentation:

Group (A) "terms" (opening no positions, filling some positions):

(i) referential expressions (1) proper names, (2) substantival pronouns: ja, ty, to, tamto,etc.;

(ii) referential expressions (3) spatio-temporal adverbial pronouns: tu, teraz, tam, wtedy, tędy, stamtą, etc.;

(iii) simple predicates: generic names (natural kinds and artifacts): brzoza, sasanka, lew, wiewiórka, etc., dom, stót, filiżanka, etc., but not: sąsiad, ojciec, stolica, brzeg, etc.;

(iv) pronominal substitutes of elements of the classes above: ktoś, coś, kto, co, gdzie, kiedy, etc. 
Group (B) independent predicates (opening some positions, filling no positions)

(i) personal and impersonal forms of verbs: zarzadzono [zbiórkę]; należało [to zrobić], chce $[$ mi] się $[p \nmid a k a c ́]$, tamie [mnie w kościach], etc.;

(ii) predicatives of the type: mito mi, zal mi, duszno tu; zimno tu, etc.; some impersonal verbs: [tu teraz] dnieje, świta, pada, padało, zagrzmiało, etc.;

(iii) participles: pracujac, widzac, wchodzac, uwzględniwszy, przyjrzawszy się, etc.;

(iv) numerals; adjectives; adjectival participles; adverbs;

(v) words of the type: bardzo, niemal, prawie, całkiem, zbyt, dość, około [stu], tuz [za płotem], etc. (metapredicative expressions: intensifiers, limitators, approximators);

Group (C) dependent predicates (filling some positions and at the same time opening positions of their own)

(i) deverbal and relational nouns: pranie, odpoczynek, przerwa, sasiad, środek, etc.;

(ii) infinitives: jeść, tęsknić, chodzić, prosić, etc.;

(iii) comparative degree: lepiej [niż ja], szczuplejsza [od niej], etc.;

(iv) prepositions: pod, w, z, na, bez, dla, podczas, wobec, z powodu, niz, etc.;

(v) includers: $\dot{z} e, \dot{z} e b y, a b y, c z y$, etc.

The most important gain at this stage of our investigation consists in establishing class A which deserves utmost attention. Further observations should show mutual relations between all the three classes. Prohibitions affecting concatenations of elements of the classes do not apply to the classes in their totality; this creates grounds for expecting sensible internal divisions of the classes.

\section{The division of paratactemes}

Combinability of paratactemes is marked for its exceptional freedom. They seem to embrace syntactemes as fillers of the positions they open, but since they do not give rise to any expectations concerning meanings of the lexemes which can fill those positions (this is their criterial requirement), they do not enter concatenations with syntactemes in the strict syntactic sense. All further observations confirm the deep differences between the two classes.

Syntactemes open positions which are severely regimented both with respect to their meanings and the classes. ${ }^{14}$ In the domain of paratactemes this kind of

\footnotetext{
${ }^{14}$ Certain restrictions affect even metapredicative uses of words (cf. intensifiers such as bardzo which do not join nouns, including nouns whose meaning admits an appraisal of intensivity of a given property, cf. bardzo wspótczuje, bardzo wspótczujący, bardzo wspótczująco, but: wielkie wspótczucie). However, my earlier formulating of the criteria of division were formulated in a less precise way (cf. Wajszczuk 1997: p. 53); this has led to the error of the treatment of metapredicative expressions (which earlier were called metatextual determiners) as a subclass of synsyntagmatics (in the new terminology - paratactemes). The necessary self-correction was introduced in Wajszczuk (2005: 105-121), where one can also find a change in terminology and its justification.
} 
limitation does not work. Particles can even accompany prepositions (Chyba przed lepiej niż po; Poruszat się sprawnie nawet bez laski. Parę żarówek umieścitem też $z a$, żeby podświetlić; za a nawet przeciw); in exceptional cases they can accompany includers (chyba, że jutro; chyba, żeby go sprowokować, tylko że nie wiem; this question requires a special reflection). Conjunctions can serve in combinations of all kinds of syntactemes ( $z a$ i przeciw; $i$ przed, $i$ za, etc.). Paratactemes do not determine the syntactic rank of expressions entering the positions opened by them; they admit the filling of a position by a sentential expression without subordinating it in the syntactic sense (cf. Przypuszczam, że mu było przykro $i \dot{z} e$ sie skarżyt na mnie.). Certain definite groups of syntactemes also admit the filling of a position opened by them with a sentential expression, but this proceeds by using special intermediary expressions (includers) while the sentence itself is subordinated in the process (such situations are strictly regimented). Cf.: Styszałam, co mówit / że wrócit. Chciat, żebym przyszła. vs. Wstat $i$ wyszedt., Spadt z konia i mocno się pottukt. Chciał coś powiedzieć, lecz nie mógt. Przewrócił się, bo było ślisko. ${ }^{15}$

In the traditional syntactic description all these properties were reduced to the common denominator of syntactic relations and classed as either coordinate or subordinate according to meaning relations between the members as expressed by the conjunction at hand (e.g., the sentence Przewrócił się, bo było ślisko. was considered materializing subordination because of the use of a causal conjunction). All of this was contrary to the obvious differences in the nature of the corresponding links arising on the basis of the contrasts discussed at length earlier on.

The division of the paratactemes in groups (D) and (E) cf. below Schema 3, requires a complete change of the character of the applied criteria. They exhibit exceptional freedom: (i) they do not fill the positions opened by them, i.e. do not complement the meaning of any lexeme by their own meaning; (ii) they may seem to embrace syntactemes in positions opened by them, but the positions are not marked for a definite meaning, i.e. they create no expectations concerning meanings of the lexemes which are to fill those positions; (iii) lexemes which enter those positions do not complement their meanings in terms of their own meanings. The types of relation arising in this domain are unique. This is a sui generis combinability and sui generis syntax. The categorial difference in question is yet to be brought into relief.

My earlier attempts at differentiating the field of paratactemes (cf. Wajszczuk 1997; in particular p. 91) allowed me to become aware of the fact that these operators require an altogether different approach than what is known in the literature of the subject. Words such as conjunctions or particles are operators of the "syntax of utterance" built, so to speak, above the ordinary syntax of sentence. This makes it mandatory to avail oneself of concepts pertaining to information articulation (theme-rheme structure) in characterizing positions which are opened by them and to interpret the words themselves in terms of meta-utterance meanings. This

\footnotetext{
${ }^{15}$ According to the requirements of this division operators of the type $\dot{z} e, i \dot{z}$, a $\dot{z} e b y, \dot{z} e b y$, $a b y, b y, c z y$ cannot be called conjunctions because they are involved in the basic syntax of the respective sentences. Attention to the special status of this class was called already by Karolak (cf. the entry spójnik in EJO (1993)).
} 
opens the possibility of contrasting particles as operators which open one position only and express a comment on the relevant part of utterance with conjunctions which open two positions for expressions and adjoining an additional, "extra" part of utterance. Certain new criteria allow us to make the division much more detailed in its character.

Here, then, is a generalized picture of paratactemes:

P -I. Whether or not the item enters a position opened for it?

PARATACTEMES

P - II. Whether or not the item opens on its right-hand side an unregimented position?

P -III. Whether or not the item opens on its left-hand side an unregimented position?

P -IV. Whether or not the item opens operates on whole thematic-rhematic structures?

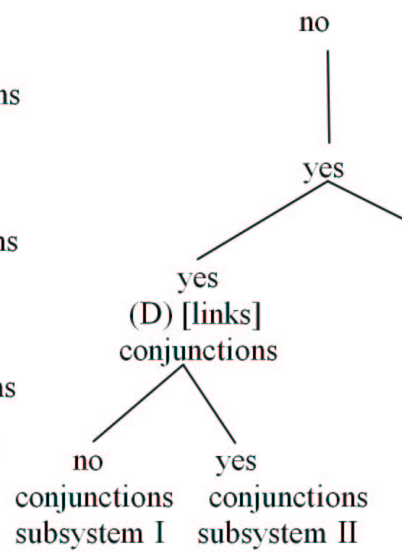

(S1)

(S2) no

(E)[is adjoined]

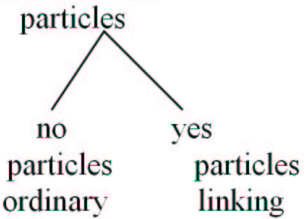

(P1)

Schema 3. Division of paratactemes according to the criteria adjusted to their properties.

We have thus established four main groups of paratactemes: two subsystems of conjunctions proper and two separate classes of particles. Conjunctions constitute closed classes; particles are only illustrated with examples. Here is the relevant illustrative picture:

(S1) so called serial conjunctions; logical conjunction and its varieties: $i, l u b, n i$, a, albo, ani

(S2) so called central conjunctions; implication and its varieties: czyli, to, tote $\dot{z}$, lecz, ale, bo, gdyż, albowiem

(P1) :

(a) so called modal particles: chyba, może, prawdopodobnie, na pewno, etc.

(b) particles proper: tylko, nawet, właśnie, głównie, właściwie, etc. (P2) :

(a) linking particles of the type: więc, bowiem, jednak, zatem, natomiast, etc.

(b) linking particles of the type: skoro, jeżeli, gdyby, poniewa $\dot{z}$, chocia $\dot{z}$, jakkolwiek (so called improper conjunctions)

The main change introduced in this version of the division consists in viewing operators of the type: skoro, jeżeli, gdyby, ponieważ, chociaż, jakkolwiek as a 
kind of particles with an embedded sentence. In an earlier version they were called "improper" or "auxiliary conjunctions"; their traditional label was "subordinate conjunctions".

The traditional vague class of conjunctions as indicators of syntactic relations has been replaced with a salient functional division of a significantly narrower class of lexemes viewed as special metaoperators dealing with the current speech flow and arising outside the syntax of sentence, arising due to special utterance-creating rules. Both subsystems of conjunctions are closed classes whose boundaries do not coincide with the non-exact division of conjunctions into coordinate and subordinate ones; it is true that that division has been, as it were, sacrosanct in the tradition. The opposition under consideration which was commonly, although ineffectively, criticized has been replaced here with the divide corresponding to the sharp question about the properties of the members of the class of conjunctions as really functioning in the capacity of metaoperators at the level of the themerheme structure of utterances. The substantial difference between conjunctions and particles can be explained in terms of their range or scope of impact: conjunctions materialize metatextual comments on structural nodes placed at a higher level than the level to which particles apply.

translated from Polish by Andrzej Bogusławski

\section{References}

Bańko, M. (2001). Z pogranicza leksykografii i językoznawstwa. Studia o słowniku jednojezzycznym. Warszawa: Wyd. Wydz. Polonistyki UW.

Bańko, M. (2002). Wykłady z polskiej fleksji. Warszawa: PWN.

Bańko, M. (2008). Współczesny polski onomatopeikon. Warszawa: PWN.

Bergernholtz, H., Schaeder, B. (1977). Die Wortarten des Deutschen Versuch einer Syntaktisch orientierten Klassifikation, Stutgart.

Bobrowski, I. (2003). Składniowy model polszczyzny, Kraków: Lexis

Bogusławski, A. (1961). O typach zależności syntagmatycznej, BPTJ XX.

Bogusławski, A. (1966). Semantyczne pojęcie liczebnika i jego morfologia w języku rosyjskim. Wrocław: Ossolineum.

Bogusławski, A. (1976). Segmenty, operacje, kategorie a morfologia imienia polskiego. In Laskowski, R. (Ed.) Kategorie gramatyczne grup imiennych w języku polskim, Wrocław 1976: Ossolineum.

Bogusławski, A. (2005). O operacjach przysłówkowych. In Grochowski, M. (Ed.) Przysłówki i przyimki w języku polskim i niemieckim. Toruń: Wyd. UMK.

Bogusławski, A. (2009). Myśli o gwiazdce i o regule. Warszawa: Bel-Studio.

Bühler, K. (1934/1999). Sprachtheorie. Die Darstellugsfunktion der Sprache, Koźbiał, J. (transl.) Teoria języka. O jezzykowej funkcji przedstawiania. Kraków (2004): Universitas.

Polański, K. (Ed.) (1993/1999). Encyklopedia językoznawstwa ogólnego. Wrocław: Ossolineum.

Fries, Ch. C. (1952). The Structure of English; An Introduction to the Construction of English Sentences, New York. 
Grochowski, M. (1984). Projekt klasyfikacji syntaktycznej polskich leksemów nieodmiennych, Polonica X.

Grochowski, M. (1986a). O metapredykatywnej funkcji niektórych wyrażeń partykułowo-przysłówkowych w strukturze tekstu. In Dobrzyńska, T. (Ed.) Teoria tekstu. Zbiór studiów. Wrocław: Ossolineum.

Grochowski, M. (1986b). Polskie partykuty. Semantyka, składnia, leksykografia, Wrocław: Ossolineum

Grochowski, M. (1997). Wyrażenia funkcyjne. Studium semantyczne. Kraków: PAN IJP.

Grochowski, M. (1998). Zmienność kontekstualna wyrażeń funkcyjnych a ich kategoryzacja gramatyczna, Z polskich studiów slawistycznych IX. Językoznawstwo. Warszawa: Energeia.

Grochowski, M. (2002). Właściwości linearne partykuł modalnych a struktura tematyczno-rematyczna wypowiedzenia, $Z$ polskich studiów slawistycznych. X. Językoznawstwo. Warszawa: PAN KSŁ i KJ.

Grochowski, M. (2003). Szyk jednostek synsyntagmatycznych w języku polskim (główne problemy metodologiczne). Polonica XXII-XXIII.

Grochowski, M. (2008). Założenia ogólne opisu tzw. wyrażeń funkcyjnych w Wielkim słowniku języka polskiego. In Żmigrodzki, P., Przybylska, R. (Eds) Nowe studia leksykograficzne, vol. 2. Kraków: Lexis

Groot de, A. W. (1948). Structural linguistics and word-classes. Lingua 1.4.

Gruszczyński W. (1987). O klasyfikacji leksemów na części mowy i opisie fleksyjnym rzeczowników w "Morfologii" IJP PAN. Studia gramatyczne 8.

Grzegorczykowa, R. (1975). Funkcje semantyczne i sktadniowe polskich przysłówków. Wrocław.

Grzegorczykowa, R. (1996). Wyktady z polskiej sktadni. Warszawa: PWN.

Grzegorczykowa, R., Laskowski, R., Wróbel, H. (Eds) (= GWJP) (1984).Gramatyka wspótczesnego języka polskiego. Morfologia. Warszawa: PWN.

Jespersen (1925/1955). Philosophy of Grammar. London: 1955.

Jodłowski, St. (1971). Studia nad częściami mowy, Warszawa: PWN.

Jodłowski, St. (1976) Podstawy polskiej sktadni, Warszawa: PWN.

Karolak, St. (1993): Spójnik, Wskaźniki syntaktyczne, Wyraz pomocniczy In Polański, K. (Ed.) Encyklopedia językoznawstwa ogólnego, Wrocław: Ossolineum.

Klemensiewicz, Z. (1953/1969). Zarys sktadni polskiej. Warszawa: PWN.

Klemensiewicz, Z. (1967). Studia syntaktyczne, part. I., part. II. (1969). Wrocław: Ossolineum.

Laskowski, R. (1981). Części mowy — problem syntaktyczny czy morfologiczny? AUL. Folia Linguistica 2.

Lyons, J. (1977). Semantics, Weinsberg, A. (transl.) Semantyka. vol. 2. Warszawa 1989: PWN.

Milewski, T. (1952). Stanowisko składni w obrębie językoznawstwa, BPTJ XI, przedr. In Lewicki, A. H. (Ed.), Problemy sktadni polskiej. Warszawa 1972: Ossolinneum.

Milewski, T (1948/1965) Językoznawstwo, Warszawa.: PWN.

Misz, H. (1967). Opis grup syntaktycznych dzisiejszej polszczyzny pisanej. Bydgoszcz: BTN. 
Misz, H. (1968) Dodatkowe wyznaczniki intelektualne ze stanowiska formalnosyntaktycznego. In Misz, H. (1981). Studia nad składnia wspótczesnej polszczyzny pisanej. Toruń: UMK.

Saloni, Z. (1974). Klasyfikacja gramatyczna leksemów polskich. Język Polski LIV. $1-2$.

Saussure de, F. (1916). Cours de linguistique générale. Paris 1955, Kasprzyk, K. (transl.), Kurs językoznawstwa ogólnego., Warszawa 1991: PWN.

Saussure, de F. (1989-1911). Écrits de linguistique générale. Paris 2002, Danielewiczowa, M. (transl.), Szkice z językoznawstwa ogólnego, Warszawa 2004: Dialog.

Śledź, A. (2003). Przerywnik czy wykrzyknik? Analiza składniowa i semantyczna pewnych użyć słów uważanych za wulgarne, Poradnik Językowy, 9.

Topolińska, Z. (1984). Semantic implication: Adjective $\rightarrow$ Noun. In Lønngren, L. (Ed.) Polish Text Linguistics, Uppsala.

Ulitzka, E. (2009), Podziały leksemów na części mowy w teorii gramatyki (przegląd propozycji klasyfikacyjnych ostatniego stulecia), Polonica XXIX.

Ulitzka, E. (2008). Słownikowy podział na części mowy w świetle zadań metaleksykografii. In Żmigrodzki, P., Przybylska, R. (Eds) Nowe studia leksykograficzne vol. 2., Kraków.

Wajszczuk, J. (1992). Czym spójniki nie są? Problem spójnika w ujęciu składniowym, "Acta Philologica" 21, Warszawa: Wyd. UW,

Wajszczuk, J. (1997). Союзы как гомогенный класс асинтаксических операторов. Предпосылки к описанию польских союзов. [Spójniki jako jednorodna klasa operatorów asyntaktycznych. Założenia do opisu polskich spójników]. In Junghanns, U., Zybatow, G. (Eds), Formale Slavistik, Frankfurt am Mein: Vervuert.

Wajszczuk, J. (1997). System znaczeń w obszarze spójników polskich. Wprowadzenie do opisu. Warszawa: KLF UW.

Wajszczuk, J. (1999). Conjunctions as agrammatical meaning correlators of syntactical constituents in their functional role in utterances. In Tošović, B. (Ed.) Die grammatischen Korrelationen, Graz: GraLiS.

Wajszczuk, J. (2000). Can a division of lexemes according to syntactic criteria be consistent? B PTJ LV.

Wajszczuk, J. (2005). O metatekście, Warszawa: KLF UW.

Wróbel, H. (1995). Problemy dyskusyjne w syntaktycznej klasyfikacji polskich leksemów. Studia gramatyczne XI.

Wróbel, H. (1996). Nowa propozycja klasyfikacji syntaktycznej polskich leksemów. In Wróbel, H. (Ed.) Studia z leksykologii i gramatyki języków słowiańskich, Kraków,

Wróbel, H. (2001). Gramatyka języka polskiego. Kraków: Od nowa.

Zaron, Z. (2003). Funkcjonalna klasyfikacja leksemów polskich (kolejna propozycja), In Gębka-Wolak, M., Kaproń-Charzyńska, I., Urban, M. (Eds), Studia z gramatyki i leksykologii języka polskiego. Prace dedykowane Profesor Marii Szupryczyńskiej, Toruń: Wyd. UMK. 
